\title{
Physiologic Specialization of Puccinia triticina on Wheat in the United States in 2002
}

\author{
J. A. Kolmer, Research Plant Pathologist, D. L. Long, Plant Pathologist, and M. E. Hughes, Biologist, United States \\ Department of Agriculture-Agricultural Research Service Cereal Disease Laboratory, Department of Plant \\ Pathology, University of Minnesota, St. Paul 55108
}

\begin{abstract}
Kolmer, J. A., Long, D. L., and Hughes, M. E. 2004. Physiologic specialization of Puccinia triticina on wheat in the United States in 2002. Plant Dis. 88:1079-1084.

Collections of Puccinia triticina were obtained from rust-infected wheat leaves by cooperators throughout the United States and from surveys of wheat fields and nurseries in the Great Plains, Ohio Valley, Southeast, California, and the Pacific Northwest, in order to determine the virulence of the wheat leaf rust fungus in 2002. Single uredinial isolates (785 in total) were derived from the wheat leaf rust collections and tested for virulence phenotype on lines of Thatcher wheat that are near-isogenic for leaf rust resistance genes $L r 1, L r 2 a, L r 2 c, L r 3, L r 9$, Lr16, Lr24, Lr26, Lr3ka, Lr11, Lr17, Lr30, LrB, Lr10, Lr14a, and Lr18. In the United States in 2002, 52 virulence phenotypes of $P$. triticina were found. Virulence phenotype MBDS, which is virulent to resistance gene $\operatorname{Lr} 17$, was the most common phenotype in the United States. MBDS was found in the Southeast, Great Plains, and the Ohio Valley regions, and also in California. Phenotype MCDS, virulent to $\operatorname{Lr} 17$ and $\operatorname{Lr} 26$, was the second most common phenotype and occurred in the same regions as MBDS. Virulence phenotype THBJ, which is virulent to Lr16 and $\operatorname{Lr} 26$, was the third most common phenotype, and was found in the southern and northern central Great Plains region. Phenotype TLGJ, with virulence to $\operatorname{Lr} 2 a, \operatorname{Lr} 9$, and $\operatorname{Lr} 11$, was the fourth most common phenotype and was found primarily in the Southeast and Ohio Valley regions. The Southeast and Ohio Valley regions differed from the Great Plains regions for predominant virulence phenotypes, which indicate that populations of $P$. triticina in those areas are not closely connected. The northern and southern areas of the Great Plains were similar for frequencies of predominant phenotypes, indicating a strong south to north migration of urediniospores.
\end{abstract}

Wheat leaf rust, caused by Puccinia triticina Eriks., occurs nearly wherever wheat is grown in North America (19). Leaf rust occurs regularly and can cause significant yield loss depending on the growth stage when the initial infections occur (1) and the effectiveness of resistance in wheat cultivars. Infections that occur during the tillering or jointing developmental stage of the wheat crop will lead to higher rust severities during grain filling, resulting in lowered kernel weight and test weight. Regions in the southeastern United States and in the southern Great Plains, where leaf rust can survive the winter on fall-planted wheat, may have fields and areas with high rust severities in the spring after the wheat has broken dormancy. Spring-planted wheat also is vulnerable when initial leaf rust infections on spring wheat are found in Minnesota

Corresponding author: J. A. Kolmer

E-mail: jkolmer@umn.edu

Accepted for publication 7 May 2004.

Publication no. D-2004-0727-03R

This article is in the public domain and not copyrightable. It may be freely reprinted with customary crediting of the source. The American Phytopathological Society, 2004. and North Dakota by mid-June before the crop has headed, which can lead to heavy leaf rust infections when the heads are filling.

Wheat cultivars with leaf rust resistance genes have been released since the mid1940s in the United States (6). The first leaf rust-resistant hard red winter wheat cultivars, such as Pawnee, had leaf rust gene Lr3. Within a few years of release, leaf rust virulence phenotypes with virulence to $L r 3$ had increased and rendered the resistance in Pawnee ineffective (6). Other early leaf rust-resistant wheat cultivars with genes $L r 1, L r 10$, and $L r 14 a$ were released in the United States and Canada, which also led to the selection of virulent leaf rust phenotypes. The frequency of $P$. triticina isolates with virulence to these resistance genes has remained over $90 \%$ in most of the wheat-growing regions of North America.

Over 45 leaf rust-resistance genes have been characterized in common bread wheat (18). Almost all of these genes condition specific resistance to leaf rust. The near-continuous use of wheat cultivars in the United States with leaf rust-resistance genes has selected $P$. triticina populations that are virulent to many of the designated $L r$ genes. Many wheat cultivars show good leaf rust resistance when initially released, yet within a few years are generally susceptible because of virulent leaf rust phenotypes. Effective leaf rust resistance in wheat cultivars can be achieved only by the use of resistance genes that condition resistance to many different leaf rust phenotypes across large geographical areas. Genes such as Lr34 that condition a nonspecific resistance that is optimally expressed in adult plants are present in many wheat cultivars $(3,24)$ that have had longlasting or durable resistance to leaf rust. Additional genes that confer nonspecific resistance need to be characterized and added to wheat improvement programs in order to develop cultivars with high levels of durable leaf rust resistance.

Wheat leaf rust virulence surveys have been conducted by the United States Department of Agriculture-Agricultural Research Service (USDA-ARS) Cereal Disease Laboratory, formerly known as the Cereal Rust Laboratory, since 1978 to detect new virulence phenotypes and to monitor shifts of virulence phenotypes in the major wheat-growing regions of the United States (15-17). Similar surveys have been done in Canada since 1931 $(4,6,8,9)$ and in Mexico (21). In the United States (16) and Canada (5), data from leaf rust surveys have been used to characterize virulence, race dynamics, and phenotypic diversity within and between wheat-growing regions. The objectives of this study were to characterize the virulence of $P$. triticina populations in the United States in 2002 to the North American wheat leaf rust differentials and to compare these results with those of previous surveys.

\section{MATERIALS AND METHODS}

Collections and virulence identification. Uredinial collections of leaf rust were made from wheat in annual surveys of the Great Plains, Ohio Valley, southeastern states, and by cooperators throughout the United States. In 2002, field surveys of wheat were made in southern and central Texas (late March); northern Texas and south-central Oklahoma (late April); southeastern states (late April to early May); Oklahoma and Kansas (late May); the Ohio River Valley (early June); northcentral Kansas, Nebraska, western Iowa, South Dakota, and southern Minnesota (mid-June); and northern Plains states (early July and again in late July). Visual inspections for the presence of rust were 
made in commercial fields (4 to 50 ha in size) every $32 \mathrm{~km}$ or in the first field thereafter. Additional collections were made in wheat breeding nurseries, trap plots, and demonstration plots along the route. Nurseries typically contain a wide array of leaf rust resistance phenotypes, including breeding lines with leaf rust resistance genes not yet in commercial cultivars. Trap plots usually contain older leaf rustsusceptible wheat cultivars that are no longer prominent in commercial production. A collection consisted of one to several leaves with uredinia from a single plant or cultivar. The leaves were air dried and stored at $4{ }^{\circ} \mathrm{C}$ until spores were collected for inoculation and increase. Collections from inoculated nurseries were not included in the study.

Urediniospores from each collection were used to inoculate 7-day-old seedlings of the wheat cv. Thatcher (CI 10003), maleic hydrazide at approximately $0.01 \mathrm{~g}$ (dissolved in $30 \mathrm{ml}$ of $\mathrm{H}_{2} \mathrm{O}$ ) per pot to enhance spore production. Plants were sprayed at a rate of approximately $0.5 \mathrm{ml}$ per pot of 10 to 20 seedlings with a suspension of spores in Soltrol 170 (Phillips Petroleum, Bartlesville OK) mineral oil. Inoculated plants were placed in a dew chamber overnight at $18^{\circ} \mathrm{C}$. The plants then were placed in plastic isolation chambers in a greenhouse where temperatures varied between 18 and $28^{\circ} \mathrm{C}$ daily under at least $8 \mathrm{~h}$ of natural light. After 12 to 15 days, three seedlings were saved per collection, each with the primary leaf trimmed to isolate a single uredinium. Then, 6 to 9 days later, a cyclone spore collector was used to collect urediniospores separately from one to three single uredinia per collection. If the single uredinia were small and few spores were collected, the isolates were increased through one uredinial generation on seedlings of treated at coleoptile emergence with

Thatcher before inoculating differential lines. Otherwise, spores from the single uredinia were mixed with $0.5 \mathrm{ml}$ of oil and directly inoculated by atomization onto 7to 8-day-old plants of the differential host series (five to seven plants per line) of near-isogenic lines of Thatcher wheat with single resistance genes $L r 1, L r 2 a, L r 2 c$, Lr3, Lr3ka, Lr9, Lr10, Lr11, Lr14a, Lr16, Lr17, Lr18, Lr24, Lr26, Lr30, and LrB. Wheat lines with genes $L r 1, L r 2 a, L r 2 c$, $L r 3$, and $L r 11$, were also in the early wheat leaf rust differential sets that were used in the United States and Canada from the 1930 s to 1960 s $(1,4,6)$. The 16 differential lines in the present-day set detect most of the virulence diversity of $P$. triticina in North America. Sets of differential lines grown during June through September received no supplemental light. From October through May, natural daylight was supplemented with high-pressure sodium lamps from 0700 to 2300 (400 to $450 \mu \mathrm{E}$ $\mathrm{m}^{-2} \mathrm{~s}^{-1}$ at bench level). After 10 to 14 days, infection types (IT) were recorded as either high (IT 3 to 4 ) or low (IT 0 to $2^{+}$) as in previous surveys (12,15-17). Race designations were assigned as described by Long and Kolmer (14). A four-letter code describes the low or high infection types of each isolate to the 16 differential lines. Each letter corresponds to the infection types of four differentials. The Thatcher lines with genes $L r 1, L r 2 a, L r 2 c$, and $L r 3$ were the four lines in the first set of differentials; lines with genes $\operatorname{Lr} 9, \operatorname{Lr} 16$, $L r 24$, and $L r 26$ were the second set of differentials; lines with genes $L r 3 k a$, Lr11, Lr17, and Lr30 were the third set of differentials; and lines with genes $\operatorname{LrB}$, Lr10, Lr14a, and Lr18 were the fourth set of differentials. Sets 1 to 3 are the same as described by Long and Kolmer (14). The same fourth set of differentials has been used in $P$. triticina surveys in Canada (8).

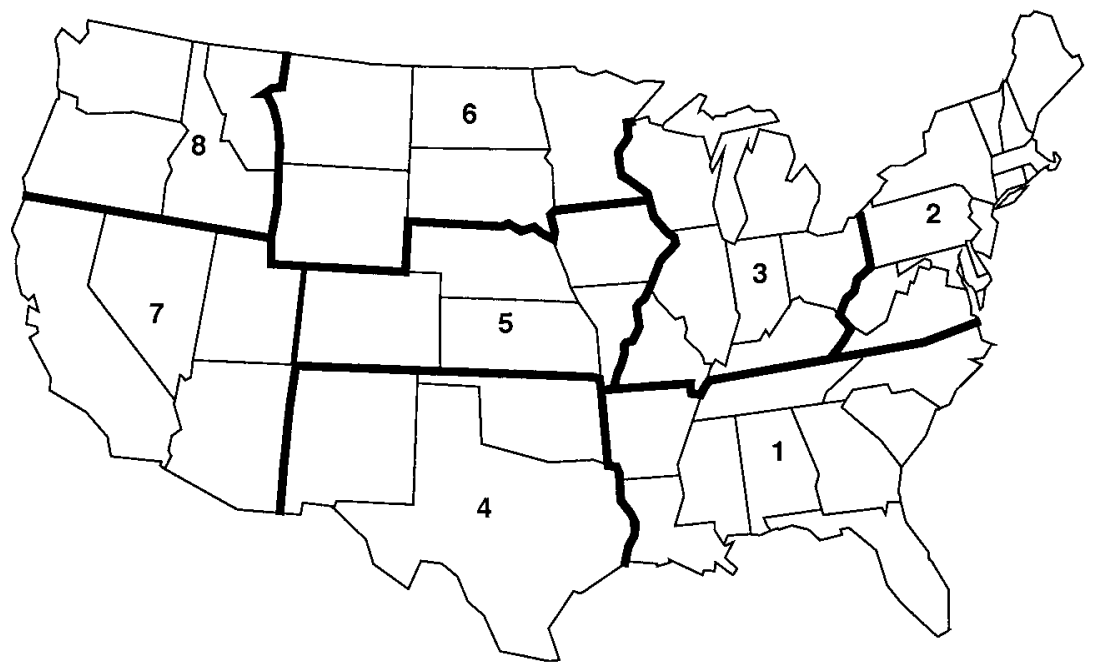

Fig. 1. Agroecological areas for Puccinia triticina in the United States. Winter wheat is grown in areas $1-5$ and 8; spring wheat is grown in areas 6 and 7. Hard red wheat cultivars are grown in areas 4-6, soft red or white cultivars in areas $1-3$, and mainly soft white cultivars in area 8.
Race and virulence frequencies were determined for collections from eight agroecological geographic areas (Fig. 1): area 1 , mainly southern-adapted soft red winter wheats; areas 2 and 3 , mostly northern-adapted soft red and white winter wheat; area 4, mixed wheat types but primarily hard red winter; area 5, hard red winter wheat; area 6 , mixed wheat types but primarily hard red spring and durum; area 7 , spring wheats planted in late fall; and area 8 , mixed wheat types but primarily soft white winter.

Diversity of virulence phenotypes within areas was determined using the Shannon index. The Shannon index of phenotypic diversity, calculated as $S h=-\Sigma p_{i} \ln \left(p_{i}\right)$ where $p_{i}=$ frequency of $i$ th virulence phenotype, was used to assess the diversity of the $P$. triticina populations in areas 1 to 7. The Shannon index normalized for number of isolates $(N)$ was also calculated by $\operatorname{Sh} / \mathrm{n}(N)$. The Shannon index reflects the number of phenotypes in a population and also the evenness of the frequency distribution of the different phenotypes (5). Shannon indices were not calculated for the isolates in area 8 , because only five isolates were obtained from this area.

\section{RESULTS}

Incidence and severity of leaf rust. In early January 2002, traces of leaf rust were first found in the United States in wheat nursery plots in central Texas in area 4 (Fig. 1). By early April, leaf rust severities of $70 \%$ were on flag leaves in wheat plots in southern and central Texas. In early May, leaf rust severities of $60 \%$ were found in wheat fields in central Texas, with lower severities in fields in northern Texas and central Oklahoma. In early May, leaf rust was severe in plots and fields in central Oklahoma.

In mid-April, trace amounts of leaf rust infections were in winter wheat plots from northeastern Louisiana through Alabama and Georgia to North Carolina in area 1 (Fig. 1). In early May, susceptible winter wheat cultivars grown from central Louisiana to central Alabama had $60 \%$ leaf rust severities. Leaf rust overwintered in eastern North Carolina, because infections could be found easily in plots of cv. Saluda in December. Winter wheat fields and plots in eastern North Carolina had high leaf rust severities from late April to early June. Moderate to heavy leaf rust severities also occurred in wheat plots and fields in Virginia and Maryland in May and June.

By mid-May, leaf rust was severe in plots and fields of susceptible cultivars in central Kansas in area 5 (Fig. 1). Cv. Jagger, which is widely grown throughout the winter wheat region of the Great Plains, had leaf rust severity of $60 \%$ on flag leaves of wheat in southern Kansas, and 5\% severity in northern Kansas in the last week of May. By the second week of June, leaf rust commonly was observed on wheat 
in southern Nebraska. Also in late May, leaf rust severities of $40 \%$ were on Aegilops cylindrica (goat grass) growing in roadside ditches in central Oklahoma and Kansas. In area 3, plots of susceptible winter wheat from northern Missouri to northwest Ohio had trace to $40 \%$ leaf rust severities.

In mid-June, traces of leaf rust were on flag leaves of winter wheat in east central South Dakota, and 10\% leaf rust severities were on flag leaves of susceptible winter wheat in east central Minnesota, in area 6 (Fig. 1). By the third week in June, traces of leaf rust were in spring wheat fields in northwestern Minnesota. In the last week of June, susceptible spring wheat plots in southern Minnesota had leaf rust severities of $40 \%$. By the third week of July, trace to $40 \%$ leaf rust severities were in spring wheats in southeastern North Dakota and northwest Minnesota. Most of the spring wheat cultivars currently grown in Minnesota and the Dakotas are moderately susceptible to leaf rust. Yield losses due to leaf rust of 2 and 3\% occurred in Minnesota and eastern and central North Dakota, respectively, in 2002 (13).

In early May, wheat fields in the Sacramento Valley of California (area 7) had heavy leaf rust infections. By mid-May, leaf rust had spread throughout the Central Valley of California, with $40 \%$ leaf rust severities on bread wheat and durum wheat cultivars. Leaf rust was at light severities in wheat fields in mid- to late July in eastern Washington State (area 8). A complete summary of the 2002 leaf rust epidemic in the United States and losses in wheat due to leaf rust can be found at the USDA-ARS Cereal Disease Laboratory website (13).

Distribution of virulence phenotypes. A total of 52 virulence phenotypes of $P$. triticina were found in the United States in 2002 (Table 1). The single-uredinial iso-

Table 1. Number and frequency (\%) of virulence phenotypes of Puccinia triticina in the United States in 2002 identified on 16 lines of Thatcher wheat near-isogenic for leaf rust resistance genes

\begin{tabular}{|c|c|c|c|c|c|c|c|c|c|c|c|c|c|c|c|c|c|c|c|}
\hline \multirow[b]{2}{*}{ Phenotype } & \multirow[b]{2}{*}{ Virulences $^{\mathbf{a}}$} & \multicolumn{2}{|c|}{ Area 1} & \multicolumn{2}{|c|}{ Area 2} & \multicolumn{2}{|c|}{ Area 3} & \multicolumn{2}{|c|}{ Area 4} & \multicolumn{2}{|c|}{ Area 5} & \multicolumn{2}{|c|}{ Area 6} & \multicolumn{2}{|c|}{ Area 7} & \multicolumn{2}{|c|}{ Area 8} & \multicolumn{2}{|c|}{ Total } \\
\hline & & No. & $\%$ & No. & $\%$ & No. & $\%$ & No. & $\%$ & No. & $\%$ & No. & $\%$ & No. & $\%$ & No. & $\%$ & No. & $\%$ \\
\hline BBBD & $14 \mathrm{a}$ & 0 & 0 & 0 & 0 & 0 & 0 & 0 & 0 & 6 & 8.3 & 1 & 0.4 & 0 & 0 & 0 & 0 & 7 & 0.9 \\
\hline FBMT & $2 \mathrm{c}, 3,3 \mathrm{ka}, 30, \mathrm{~B}, 10,14 \mathrm{a}, 18$ & 2 & 1.1 & 0 & 0 & 1 & 2.2 & 0 & 0 & 0 & 0 & 0 & 0 & 0 & 0 & 0 & 0 & 3 & 0.4 \\
\hline FMMG & $2 \mathrm{c}, 3,9,26,3 \mathrm{ka}, 30,10$ & 2 & 1.1 & 0 & 0 & 0 & 0 & 0 & 0 & 0 & 0 & 0 & 0 & 0 & 0 & 0 & 0 & 2 & 0.3 \\
\hline KBBG & $2 \mathrm{a}, 2 \mathrm{c}, 3,10$ & 0 & 0 & 0 & 0 & 0 & 0 & 0 & 0 & 2 & 2.8 & 4 & 1.6 & 0 & 0 & 0 & 0 & 6 & 0.8 \\
\hline KBBJ & $2 \mathrm{a}, 2 \mathrm{c}, 3,10,14 \mathrm{a}$ & 0 & 0 & 0 & 0 & 0 & 0 & 0 & 0 & 0 & 0 & 6 & 2.4 & 0 & 0 & 0 & 0 & 6 & 0.8 \\
\hline KGBJ & $2 \mathrm{a}, 2 \mathrm{c}, 3,16,10,14 \mathrm{a}$ & 0 & 0 & 0 & 0 & 0 & 0 & 0 & 0 & 0 & 0 & 7 & 2.8 & 0 & 0 & 0 & 0 & 7 & 0.9 \\
\hline MBBJ & $1,3,10,14 \mathrm{a}$ & 3 & 1.7 & 0 & 0 & 0 & 0 & 0 & 0 & 0 & 0 & 1 & 0.4 & 10 & 22.7 & 0 & 0 & 14 & 1.8 \\
\hline MBBS & $1,3, \mathrm{~B}, 10,14 \mathrm{a}$ & 0 & 0 & 0 & 0 & 0 & 0 & 0 & 0 & 0 & 0 & 0 & 0 & 0 & 0 & 1 & 20.0 & 1 & 0.1 \\
\hline MBDS & $1,3,17, \mathrm{~B}, 10,14 \mathrm{a}$ & 6 & 3.3 & 0 & 0 & 2 & 4.3 & 55 & 31.8 & 44 & 61.1 & 78 & 31.2 & 8 & 18.2 & 0 & 0 & 193 & 24.6 \\
\hline MBGJ & $1,3,11,10,14 \mathrm{a}$ & 7 & 3.9 & 0 & 0 & 0 & 0 & 0 & 0 & 0 & 0 & 3 & 1.2 & 6 & 13.6 & 4 & 80.0 & 20 & 2.5 \\
\hline MBJJ & $1,3,11,17,10,14 \mathrm{a}$ & 0 & 0 & 0 & 0 & 0 & 0 & 0 & 0 & 0 & 0 & 2 & 0.8 & 0 & 0 & 0 & 0 & 2 & 0.3 \\
\hline MBRJ & $1,3,3 \mathrm{ka}, 11,30,10,14 \mathrm{a}$ & 12 & 6.6 & 0 & 0 & 7 & 15.2 & 2 & 1.2 & 0 & 0 & 2 & 0.8 & 1 & 2.3 & 0 & 0 & 24 & 3.1 \\
\hline MBRK & $1,3,3 \mathrm{ka}, 11,30,10,14 \mathrm{a}, 18$ & 7 & 3.9 & 3 & 21.4 & 4 & 8.7 & 0 & 0 & 0 & 0 & 2 & 0.8 & 0 & 0 & 0 & 0 & 16 & 2.0 \\
\hline MBRS & $1,3,3 \mathrm{ka}, 11,30, \mathrm{~B}, 10,14 \mathrm{a}$ & 5 & 2.8 & 0 & 0 & 0 & 0 & 1 & 0.6 & 0 & 0 & 0 & 0 & 0 & 0 & 0 & 0 & 6 & 0.8 \\
\hline MCBJ & $1,3,26,10,14 \mathrm{a}$ & 3 & 1.7 & 0 & 0 & 2 & 4.3 & 0 & 0 & 0 & 0 & 1 & 0.4 & 6 & 13.6 & 0 & 0 & 12 & 1.5 \\
\hline MCDS & $1,3,26,17, \mathrm{~B}, 10,14 \mathrm{a}$ & 6 & 3.3 & 0 & 0 & 3 & 6.5 & 15 & 8.7 & 7 & 9.7 & 21 & 8.4 & 13 & 29.5 & 0 & 0 & 65 & 8.3 \\
\hline MCGS & $1,3,26,11, \mathrm{~B}, 10,14 \mathrm{a}$ & 2 & 1.1 & 0 & 0 & 0 & 0 & 0 & 0 & 0 & 0 & 0 & 0 & 0 & 0 & 0 & 0 & 2 & 0.3 \\
\hline MCRJ & $1,3,26,3 \mathrm{ka}, 11,30,10,14 \mathrm{a}$ & 9 & 5.0 & 0 & 0 & 0 & 0 & 0 & 0 & 0 & 0 & 0 & 0 & 0 & 0 & 0 & 0 & 9 & 1.1 \\
\hline MCRK & $1,3,26,3 \mathrm{ka}, 11,30,10,14 \mathrm{a}, 18$ & 12 & 6.6 & 4 & 28.6 & 2 & 4.3 & 0 & 0 & 0 & 0 & 0 & 0 & 0 & 0 & 0 & 0 & 18 & 2.3 \\
\hline MCRS & $1,3,26,3 \mathrm{ka}, 11,30, \mathrm{~B}, 10,14 \mathrm{a}$ & 9 & 5.0 & 0 & 0 & 0 & 0 & 1 & 0.6 & 0 & 0 & 0 & 0 & 0 & 0 & 0 & 0 & 10 & 1.3 \\
\hline MCRT & $1,3,26,3 \mathrm{ka}, 11,30, \mathrm{~B}, 10,14 \mathrm{a}, 18$ & 0 & 0 & 2 & 14.3 & 0 & 0 & 0 & 0 & 0 & 0 & 0 & 0 & 0 & 0 & 0 & 0 & 2 & 0.3 \\
\hline MDBJ & $1,3,24,10,14 \mathrm{a}$ & 1 & 0.6 & 0 & 0 & 2 & 4.3 & 0 & 0 & 0 & 0 & 1 & 0.4 & 0 & 0 & 0 & 0 & 4 & 0.6 \\
\hline MGBJ & $1,3,16,10,14 \mathrm{a}$ & 0 & 0 & 0 & 0 & 0 & 0 & 4 & 2.3 & 1 & 1.4 & 0 & 0 & 0 & 0 & 0 & 0 & 5 & 0.6 \\
\hline MGDS & $1,3,16,17, \mathrm{~B}, 10,14 \mathrm{a}$ & 0 & 0 & 0 & 0 & 2 & 4.3 & 1 & 0.6 & 0 & 0 & 0 & 0 & 0 & 0 & 0 & 0 & 3 & 0.4 \\
\hline NBBJ & $1,2 \mathrm{c}, 10,14 \mathrm{a}$ & 2 & 1.1 & 0 & 0 & 0 & 0 & 0 & 0 & 0 & 0 & 0 & 0 & 0 & 0 & 0 & 0 & 2 & 0.3 \\
\hline NBGR & $1,2 \mathrm{c}, 11, \mathrm{~B}, 10,18 \mathrm{:}$ & 2 & 1.1 & 0 & 0 & 0 & 0 & 0 & 0 & 0 & 0 & 0 & 0 & 0 & 0 & 0 & 0 & 2 & 0.3 \\
\hline PCRK & $1,2 \mathrm{c}, 3,26,3 \mathrm{ka}, 11,30,10,14 \mathrm{a}, 18$ & 2 & 1.1 & 0 & 0 & 0 & 0 & 2 & 1.2 & 0 & 0 & 0 & 0 & 0 & 0 & 0 & 0 & 4 & 0.5 \\
\hline SBDB & $1,2 \mathrm{a}, 2 \mathrm{c}, 17$ & 0 & 0 & 0 & 0 & 0 & 0 & 2 & 1.2 & 4 & 5.6 & 0 & 0 & 0 & 0 & 0 & 0 & 6 & 0.8 \\
\hline SBDD & $1,2 \mathrm{a}, 2 \mathrm{c}, 17,14 \mathrm{a}$ & 1 & 0.6 & 0 & 0 & 0 & 0 & 0 & 0 & 0 & 0 & 0 & 0 & 0 & 0 & 0 & 0 & 1 & 0.1 \\
\hline TBBG & $1,2 \mathrm{a}, 2 \mathrm{c}, 3,10$ & 0 & 0 & 0 & 0 & 0 & 0 & 2 & 1.2 & 1 & 1.4 & 0 & 0 & 0 & 0 & 0 & 0 & 3 & 0.4 \\
\hline TBBJ & $1,2 \mathrm{a}, 2 \mathrm{c}, 3,10,14 \mathrm{a}$ & 2 & 1.1 & 0 & 0 & 0 & 0 & 1 & 0.6 & 0 & 0 & 25 & 10.0 & 0 & 0 & 0 & 0 & 28 & 3.6 \\
\hline TBDJ & $1,2 \mathrm{a}, 2 \mathrm{c}, 3,17,10,14 \mathrm{a}$ & 0 & 0 & 0 & 0 & 2 & 4.3 & 2 & 1.2 & 0 & 0 & 1 & 0.4 & 0 & 0 & 0 & 0 & 5 & 0.6 \\
\hline TBDS & $1,2 \mathrm{a}, 2 \mathrm{c}, 3,17, \mathrm{~B}, 10,14 \mathrm{a}$ & 1 & 0.6 & 0 & 0 & 0 & 0 & 1 & 0.6 & 0 & 0 & 17 & 6.8 & 0 & 0 & 0 & 0 & 19 & 2.4 \\
\hline TBRJ & $1,2 \mathrm{a}, 2 \mathrm{c}, 3,3 \mathrm{ka}, 11,30,10,14 \mathrm{a}$ & 0 & 0 & 0 & 0 & 3 & 6.5 & 0 & 0 & 0 & 0 & 1 & 0.4 & 0 & 0 & 0 & 0 & 4 & 0.5 \\
\hline TCBJ & $1,2 \mathrm{a}, 2 \mathrm{c}, 3,26,10,14 \mathrm{a}$ & 2 & 1.1 & 0 & 0 & 2 & 4.3 & 4 & 2.3 & 2 & 2.8 & 4 & 1.6 & 0 & 0 & 0 & 0 & 14 & 1.8 \\
\hline TCDS & $1,2 \mathrm{a}, 2 \mathrm{c}, 3,26,17, \mathrm{~B}, 10,14 \mathrm{a}$ & 0 & 0 & 0 & 0 & 0 & 0 & 2 & 1.2 & 2 & 2.8 & 8 & 3.2 & 0 & 0 & 0 & 0 & 12 & 1.5 \\
\hline TCRJ & $1,2 \mathrm{a}, 2 \mathrm{c}, 3,26,3 \mathrm{ka}, 11,30,10,14 \mathrm{a}$ & 5 & 2.8 & 0 & 0 & 0 & 0 & 0 & 0 & 0 & 0 & 0 & 0 & 0 & 0 & 0 & 0 & 5 & 0.6 \\
\hline TCTF & $1,2 \mathrm{a}, 2 \mathrm{c}, 3,26,3 \mathrm{ka}, 11,17,30,14 \mathrm{a}, 18$ & 0 & 0 & 4 & 28.6 & 0 & 0 & 0 & 0 & 0 & 0 & 0 & 0 & 0 & 0 & 0 & 0 & 4 & 0.5 \\
\hline TDBJ & $1,2 \mathrm{a}, 2 \mathrm{c}, 3,24,10,14 \mathrm{a}$ & 1 & 0.6 & 0 & 0 & 1 & 2.2 & 2 & 1.2 & 0 & 0 & 2 & 0.8 & 0 & 0 & 0 & 0 & 6 & 0.8 \\
\hline TFBJ & $1,2 \mathrm{a}, 2 \mathrm{c}, 3,24,26,10,14 \mathrm{a}$ & 2 & 1.1 & 0 & 0 & 1 & 2.2 & 0 & 0 & 0 & 0 & 1 & 0.4 & 0 & 0 & 0 & 0 & 4 & 0.5 \\
\hline TFGJ & $1,2 \mathrm{a}, 2 \mathrm{c}, 3,24,26,11,10,14 \mathrm{a}$ & 2 & 1.1 & 0 & 0 & 0 & 0 & 0 & 0 & 0 & 0 & 0 & 0 & 0 & 0 & 0 & 0 & 2 & 0.3 \\
\hline TGBG & $1,2 \mathrm{a}, 2 \mathrm{c}, 3,16,10$ & 0 & 0 & 0 & 0 & 0 & 0 & 0 & 0 & 1 & 1.4 & 0 & 0 & 0 & 0 & 0 & 0 & 1 & 0.1 \\
\hline TGBJ & $1,2 \mathrm{a}, 2 \mathrm{c}, 3,16,10,14 \mathrm{a}$ & 0 & 0 & 0 & 0 & 0 & 0 & 0 & 0 & 0 & 0 & 5 & 2.0 & 0 & 0 & 0 & 0 & 5 & 0.6 \\
\hline TGDS & $1,2 \mathrm{a}, 2 \mathrm{c}, 3,16,17, \mathrm{~B}, 10,14 \mathrm{a}$ & 0 & 0 & 0 & 0 & 0 & 0 & 0 & 0 & 0 & 0 & 6 & 2.4 & 0 & 0 & 0 & 0 & 6 & 0.8 \\
\hline THBJ & $1,2 \mathrm{a}, 2 \mathrm{c}, 3,16,26,10,14 \mathrm{a}$ & 0 & 0 & 0 & 0 & 0 & 0 & 18 & 10.4 & 0 & 0 & 40 & 16.0 & 0 & 0 & 0 & 0 & 58 & 7.4 \\
\hline TKBJ & $1,2 \mathrm{a}, 2 \mathrm{c}, 3,16,24,26,10,14 \mathrm{a}$ & 0 & 0 & 0 & 0 & 0 & 0 & 2 & 1.2 & 0 & 0 & 4 & 1.6 & 0 & 0 & 0 & 0 & 6 & 0.8 \\
\hline TLBJ & $1,2 \mathrm{a}, 2 \mathrm{c}, 3,9,10,14 \mathrm{a}$ & 2 & 1.1 & 0 & 0 & 0 & 0 & 1 & 0.6 & 0 & 0 & 0 & 0 & 0 & 0 & 0 & 0 & 3 & 0.4 \\
\hline TLGG & $1,2 \mathrm{a}, 2 \mathrm{c}, 3,9,11,10$ & 1 & 0.6 & 0 & 0 & 0 & 0 & 0 & 0 & 0 & 0 & 0 & 0 & 0 & 0 & 0 & 0 & 1 & 0.1 \\
\hline TLGJ & $1,2 \mathrm{a}, 2 \mathrm{c}, 3,9,11,10,14 \mathrm{a}$ & 39 & 21.5 & 1 & 7.1 & 9 & 19.6 & 6 & 3.5 & 0 & 0 & 2 & 0.8 & 0 & 0 & 0 & 0 & 57 & 7.3 \\
\hline TLGS & $1,2 \mathrm{a}, 2 \mathrm{c}, 3,9,11, \mathrm{~B}, 10,14 \mathrm{a}$ & 15 & 8.3 & 0 & 0 & 1 & 2.2 & 0 & 0 & 0 & 0 & 0 & 0 & 0 & 0 & 0 & 0 & 16 & 2.0 \\
\hline TNGJ & $1,2 \mathrm{a}, 2 \mathrm{c}, 3,9,24,11,10,14 \mathrm{a}$ & 11 & 6.1 & 0 & 0 & 1 & 2.2 & 10 & 5.8 & 0 & 0 & 0 & 0 & 0 & 0 & 0 & 0 & 22 & 2.8 \\
\hline TNRJ & $1,2 \mathrm{a}, 2 \mathrm{c}, 3,9,24,3 \mathrm{ka}, 11,30,10,14 \mathrm{a}$ & 5 & 2.8 & 0 & 0 & 1 & 2.2 & 39 & 22.5 & 2 & 2.8 & 5 & 2.0 & 0 & 0 & 0 & 0 & 52 & 6.6 \\
\hline Total & $\ldots$ & 181 & $\ldots$ & 14 & $\ldots$ & 46 & $\ldots$ & 173 & $\ldots$ & 72 & $\ldots$ & 250 & $\ldots$ & 44 & $\ldots$ & 5 & $\ldots$ & 785 & $\ldots$ \\
\hline
\end{tabular}

a Ineffective $L r$ genes. 
lates (785 in total) derived from collections made in the United States were tested for virulence. Phenotypes MBDS (24.6\%), MCDS (8.3\%) THBJ (7.4\%), TLGJ (7.3\%), and TNRJ (6.6\%) were the five most common phenotypes in the United States in 2002.

In the southeastern states (area 1), 30 virulence phenotypes were found among the 181 isolates tested in 2002 (Table 1). Phenotypes TLGJ (21.5\%) and TLGS $(8.3 \%)$ were the two most common phenotypes, because no other phenotype occurred at greater than $8 \%$ in this area. In the Northeastern states (area 2), phenotypes MCRK (28.6\%), TCTF (28.5\%), and MBRK (21.4\%) were the most common of the five phenotypes found among the 14 isolates that were tested from the area in 2002. In the Ohio Valley states (area 3), 18 virulence phenotypes were found among the 46 isolates that were tested. Phenotypes TLGJ (19.6\%) and MBRJ (15.2\%) were the most common, because no other phenotypes occurred at greater than $10 \%$ in this area.

In the southern Great Plains (area 4), 22 virulence phenotypes were described among the 173 isolates. Phenotypes MBDS (31.8\%), TNRJ (22.5\%), and THBJ $(10.4 \%)$ were the three most common phenotypes, because no other phenotypes occurred at greater than $10 \%$. In the central Great Plains (area 5), phenotypes MBDS $(61.1 \%)$, MCDS $(9.7 \%)$, and BBBD $(8.3 \%)$ were the three most common of the 11 phenotypes described from the 72 isolates in this area. In the northern plains (area 6), phenotypes MBDS (31.2\%), THBJ (16.0\%), TBBJ (10.0\%), and MCDS $(8.4 \%)$ were the most common of the 27 virulence phenotypes from the 250 isolates from this area.

In California (area 7), six phenotypes were described among the 44 isolates tested. Phenotypes MCDS (29.5\%), MBBJ $(22.7 \%)$, and MBDS (18.2\%) were the three most common phenotypes. In Wash- ington (area 8), four isolates of phenotypes MBGJ and one isolate of MBBS were found in 2002. A complete listing of the $P$. triticina virulence phenotypes from the 2002 survey can be found at the USDA-ARS Cereal Disease Laboratory website.

Virulence frequencies. Frequencies of virulence differed among populations of $P$. triticina in the United States in 2002 (Table 2). Virulence to $\operatorname{Lr} 2 a$ varied from 19.4 to $55.2 \%$ in areas 1 to 6 , and did not occur in areas 7 and 8 . Virulence to $L r 2 c$ is highly associated with virulence to $L r 2 a$ (2). Virulence frequencies to $L r 2 c$ were the same as to $L r 2 a$ in areas 2, 5, 6, 7, and 8; and were slightly higher in areas 1 and 4 . Virulence to $\operatorname{Lr} 9$ was between 0.0 and $7.1 \%$ in areas $2,5,6,7$, and 8 and occurred at 26.1 to $41.4 \%$ in areas 1,3 , and 4 . Virulence to Lrl6 occurred only in area 4 $(14.5 \%)$, area $5(2.8 \%)$, and area $6(24.8 \%)$. Virulence to $\mathrm{Lr} 24$ was at $0.0 \%$ in areas 2, 7, and 8; 2.8 and $5.2 \%$ in areas 5 and 6 , respectively; and between 12.2 and $30.6 \%$ in areas 1, 3, and 4. Virulence to $\operatorname{Lr} 26$ was $3,4,5,6$, and 7, virulence to $\operatorname{Lr} 26$ was between 15.3 and $31.6 \%$. In area 2 , virulence to $\operatorname{Lr} 26$ was at $71.4 \%$.

Virulence to Lr3ka did not occur in area 8 , and was between 2.3 and $4.0 \%$ in areas 5,6 , and 7. Virulence to Lr3ka was between 26.0 and $92.9 \%$ in areas 1, 2, 3, and 4. Virulence to $\operatorname{Lr} 30$ is highly associated with virulence to $L r 3 k a$ (20). Virulence frequencies to both $L r 3 k a$ and $L r 30$ were found in all areas except area 8 . In areas 1 ,

the same in all areas in 2002. Virulence to LrII was less than $10 \%$ in areas 5 and 6; 15.9 and $35.3 \%$ in areas 7 and 4 , respectively; $60.9 \%$ in area $3 ; 80.1 \%$ in area 1 ; and $100 \%$ in area 2 . Virulence to $\mathrm{Lr} 17$ did not occur in area 8; was at $7.7 \%$ in area 1 ; between 19.6 and $47.7 \%$ in areas 2, 3, 4, and 7 ; at $53.2 \%$ in area 6 , and at $79.2 \%$ in area 5. Virulence to $\operatorname{LrB}$ was between $14.3 \%$ and $47.7 \%$ in areas $1,2,3,4,7$, and $8 ; 52 \%$ in area 6 ; and $73.6 \%$ in area 5 . Almost all isolates that were virulent to $\operatorname{Lr} B$ also were virulent to $\operatorname{Lr} 17$. Virulence to $L r 1, L r 10$, and $L r 14 a$ was greater than $90 \%$ in all areas except area 5. Virulence to Lr18 did not occur in areas 5, 7, and 8; was between 0.8 and $15.2 \%$ in areas $1,3,4$, and 6; and at $92.9 \%$ in area 2 .

Diversity of virulence phenotypes. Using the standard Shannon index (Table $3)$, the $P$. triticina population in area 1 , with 30 virulence phenotypes, was the most diverse. The populations in areas 3 , 6 , and 4 , with 18,27 , and 22 , virulence phenotypes, respectively, were the next most diverse using the standard Shannon index. The populations in areas 7,2 , and 5, with 6, 5, and 11 phenotypes, respectively, were the least diverse. The ranking of the $P$. triticina populations for diversity changed markedly when the Shannon index corrected for sample size (number of isolates) was used. The population in area 3 was the most diverse, followed by areas 1 and 2 in a tie, and then by area 6 , areas 4 and 7 in a tie, and area 5 as the least diverse.

Table 3. Shannon measures of phenotypic diversity for Puccinia triticina in seven geographical areas of the United States in $2002^{\mathrm{a}}$

\begin{tabular}{lccccccc}
\hline Area & $\mathbf{1}$ & $\mathbf{2}$ & $\mathbf{3}$ & $\mathbf{4}$ & $\mathbf{5}$ & $\mathbf{6}$ & $\mathbf{7}$ \\
\hline Number of isolates $(N)$ & 181 & 14 & 46 & 173 & 72 & 250 & 44 \\
Number of phenotypes & 30 & 5 & 18 & 22 & 11 & 27 & 6 \\
Shannon index & 2.982 & 1.510 & 2.624 & 2.212 & 1.475 & 2.422 & 1.636 \\
Shannon index/ $(\ln N)$ & 0.57 & 0.57 & 0.68 & 0.43 & 0.34 & 0.44 & 0.43 \\
\hline
\end{tabular}

a The Shannon index of phenotypic diversity is calculated as $S h=-\Sigma p_{i} \ln \left(p_{i}\right)$ where $p_{i}=$ frequency of $i$ th virulence phenotype.

Table 2. Number and frequency (\%) of isolates of Puccinia triticina in the United States in 2002 virulent on 16 lines of Thatcher wheat near-isogenic for leaf rust resistance genes

\begin{tabular}{|c|c|c|c|c|c|c|c|c|c|c|c|c|c|c|c|c|c|c|}
\hline \multirow[b]{2}{*}{ Gene } & \multicolumn{2}{|c|}{ Area 1} & \multicolumn{2}{|c|}{ Area 2} & \multicolumn{2}{|c|}{ Area 3} & \multicolumn{2}{|c|}{ Area 4} & \multicolumn{2}{|c|}{ Area 5} & \multicolumn{2}{|c|}{ Area 6} & \multicolumn{2}{|c|}{ Area 7} & \multicolumn{2}{|c|}{ Area 8} & \multicolumn{2}{|c|}{ Total } \\
\hline & No. & $\%$ & No. & $\%$ & No. & $\%$ & No. & $\%$ & No. & $\%$ & No. & $\%$ & No. & $\%$ & No. & $\%$ & No. & $\%$ \\
\hline Lrl & 177 & 97.8 & 14 & 100.0 & 45 & 97.8 & 173 & 100.0 & 64 & 88.9 & 232 & 92.8 & 44 & 100.0 & 5 & 100.0 & 754 & 96.1 \\
\hline$L r 2 a$ & 89 & 49.2 & 5 & 35.7 & 21 & 45.7 & 92 & 53.2 & 14 & 19.4 & 138 & 55.2 & 0 & 0 & 0 & 0 & 359 & 45.7 \\
\hline $\operatorname{Lr} 2 c$ & 99 & 54.7 & 5 & 35.7 & 22 & 47.8 & 94 & 54.3 & 14 & 19.4 & 138 & 55.2 & 0 & 0 & 0 & 0 & 372 & 47.4 \\
\hline Lr3 & 176 & 97.2 & 14 & 100.0 & 46 & 100.0 & 171 & 98.8 & 62 & 86.1 & 249 & 99.6 & 44 & 100.0 & 5 & 100.0 & 767 & 97.7 \\
\hline $\operatorname{Lr} 9$ & 75 & 41.4 & 1 & 7.1 & 12 & 26.1 & 56 & 32.4 & 2 & 2.8 & 7 & 2.8 & 0 & 0 & 0 & 0 & 153 & 19.5 \\
\hline Lr16 & 0 & 0 & 0 & 0 & 2 & 4.3 & 25 & 14.5 & 2 & 2.8 & 62 & 24.8 & 0 & 0 & 0 & 0 & 91 & 11.6 \\
\hline Lr24 & 22 & 12.2 & 0 & 0 & 6 & 13.0 & 53 & 30.6 & 2 & 2.8 & 13 & 5.2 & 0 & 0 & 0 & 0 & 96 & 12.2 \\
\hline Lr26 & 56 & 30.9 & 10 & 71.4 & 10 & 21.7 & 44 & 25.4 & 11 & 15.3 & 79 & 31.6 & 19 & 43.2 & 0 & 0 & 229 & 29.2 \\
\hline Lr3ka & 70 & 38.7 & 13 & 92.9 & 18 & 39.1 & 45 & 26.0 & 2 & 2.8 & 10 & 4.0 & 1 & 2.3 & 0 & 0 & 159 & 20.3 \\
\hline Lr11 & 145 & 80.1 & 14 & 100.0 & 28 & 60.9 & 61 & 35.3 & 2 & 2.8 & 17 & 6.8 & 7 & 15.9 & 4 & 80.0 & 278 & 35.4 \\
\hline Lr17 & 14 & 7.7 & 4 & 28.6 & 9 & 19.6 & 78 & 45.1 & 57 & 79.2 & 133 & 53.2 & 21 & 47.7 & 0 & 0 & 316 & 40.3 \\
\hline Lr30 & 70 & 38.7 & 13 & 92.9 & 18 & 39.1 & 45 & 26.0 & 2 & 2.8 & 10 & 4.0 & 1 & 2.3 & 0 & 0 & 159 & 20.3 \\
\hline$L r B$ & 48 & 26.5 & 2 & 14.3 & 9 & 19.6 & 76 & 43.9 & 53 & 73.6 & 130 & 52.0 & 21 & 47.7 & 1 & 20.0 & 340 & 43.3 \\
\hline Lr10 & 180 & 99.4 & 10 & 71.4 & 46 & 100.0 & 171 & 98.8 & 62 & 86.1 & 249 & 99.6 & 44 & 100.0 & 5 & 100.0 & 767 & 97.7 \\
\hline Lr14a & 176 & 97.2 & 14 & 100.0 & 46 & 100.0 & 169 & 97.7 & 64 & 88.9 & 246 & 98.4 & 44 & 100.0 & 5 & 100.0 & 764 & 97.3 \\
\hline Lr18 & 25 & 13.8 & 13 & 92.9 & 7 & 15.2 & 2 & 1.2 & 0 & 0 & 2 & 0.8 & 0 & 0 & 0 & 0 & 49 & 6.2 \\
\hline Total & 181 & $\ldots$ & 14 & $\ldots$ & 46 & $\ldots$ & 173 & $\ldots$ & 72 & $\ldots$ & 250 & $\ldots$ & 44 & $\ldots$ & 5 & $\ldots$ & 785 & $\ldots$ \\
\hline
\end{tabular}




\section{DISCUSSION}

The virulence phenotypes of $P$. triticina in 2002 in the United States showed strong regional distribution caused by the presence of different leaf rust-resistance genes in the various wheat classes that are grown across the country. Phenotype TLGJ was the most common phenotype in areas 1 and 3 . This phenotype is virulent to genes $L r 2 a, L r 9, L r 10$, and Lr11. Cvs. CK 9835 (Lr2a and Lr9), CK 9663 (Lr2a, Lr9, and Lr10), Saluda (Lr11), Pocahontas (Lr11), Pioneer 2580 (Lrl1), Cardinal (LrlO), and FFR555W ( r 10) are grown in areas 1, 2, and 3 (11). Phenotype MBDS was the most common phenotype throughout the Great Plains region in areas 4, 5, and 6. This phenotype and other phenotypes with virulence to $L r 17$ have been selected by cv. Jagger (Lr17) (D. L. Long, unpublished data), which is the most commonly grown wheat in Kansas and also is grown in other southern and mid-Great Plains states in areas 4 and 5. Phenotypes MBDS and MCDS are now widespread throughout the United States, because these also were found in areas 1, 3, and 7 in 2002. MBDS and MCDS were found at very low frequencies throughout the United States previous to release of Jagger in the mid1990s. MBDS occurred at 2, 3, and 0\% in area 5 in 1993, 1994, and 1995, respectively; in area 4, MCDS was at 0\% in 1993 and 2\% in 1994 and 1995 (16).

Phenotypes MBRK and MCRK were found in areas 1, 2, and 3 in 2002. These phenotypes were very common in 1999 in Georgia, South Carolina, North Carolina, and Virginia (10), and in area 1 in 2001 (12). MBRK and MCRK have declined in frequency in the eastern United States because they are avirulent to $L r 2 a$ and $L r 9$, which are present in many of the soft red winter wheat cultivars in area 1 (11). Phenotype TNRJ was the second most common phenotype in area 4 , and has been selected by virulence to gene Lr41. Cv. Thunderbolt with Lr41 (D. L. Long, unpublished data) has been grown in Texas since 2000. The rapid emergence of $P$. triticina phenotypes with virulence to $L r 41$ will limit the long-term effectiveness of this resistance gene. Five isolates of TNRJ also were found in Minnesota in 2002 on the winter wheat Lockett that probably has genes Lr9 and Lr24 (D. Long, unpublished data). In the northern plains of area 6 , THBJ was the second most common phenotype. THBJ is virulent to genes $L r 2 a$, Lr16, and Lr26. Genes Lr2a and Lr16 are in many of the hard red spring wheats, such as Norpro, Forge, Parshall, and Ember, that are grown in area 6 (J. Kolmer, unpublished data). THBJ also was found in the southern plains of area 4. Isolates of $P$. triticina with virulence to Lrl6 previously were found in Texas selected by cv. Probrand 812 (17). Some current cultivars in Texas and Oklahoma, such as Gem, Millennium, and Arapahoe, may have Lr16. Cultivars with Lr26, such as Tam 302 and Nekota, are grown in Texas, Oklahoma, and Kansas in areas 4 and 5. Soft red winter wheats, such as Patton, Foster, and Pioneer 26R61, with Lr26 are grown in areas 1, 2, and 3 (11). Wheats with $L r 26$ have selected races such as MCRK, which was found in areas 1, 2, and 3.

Epidemiological zones of $P$. triticina in the United States can be inferred by the distribution of virulence phenotypes in the different regions. The two most common phenotypes in the southeastern states of area 1, TLGJ and TLGS, were not found or occurred at very low frequencies in the Great Plains region of areas 4, 5, and 6. Phenotypes MBDS, MCDS, and THBJ were important virulence phenotypes throughout the Great Plains region in areas 4, 5, and 6 and also in California (area 7), but occurred at low frequencies in the eastern regions of areas 1,2, and 3. Urediniospores on winter wheats in Texas and Oklahoma are carried on the southerly winds to the northern winter wheat area in area 5 and to the spring wheats of area 6 . Leaf rust virulence phenotypes MBDS, MBRJ, MCRK, and TLGJ, which were found in the Ohio Valley states of area 3, also were found in area 1 or in areas 4 and 5. Urediniospores from the southeastern states and southern to mid-Great Plains states are windborne to wheat fields in the Ohio Valley area. For most of the areas described in 2002, differences in $L r$ genes present in the different classes of wheat (soft red winter, hard red winter, hard red spring, and soft white winter) that are grown in the various regions of the United States have led to the establishment of relatively distinct phenotypic populations of $P$. triticina.

The $P$. triticina populations in the United States remain highly diverse for virulence phenotypes that have no apparent selective advantage on wheat cultivars. Phenotypes SBDB and SBDD were collected from Aegilops cylindrica (common goat grass) in Kansas and Oklahoma. These two phenotypes are avirulent to gene $L r 3$, which is in many of the winter wheats in the southern plains. These phenotypes are remnants of a group of $P$. triticina phenotypes that were very common and widely distributed in North America in the 1930s and early 1940s, prior to the use of wheat cultivars with $L r 3$ (6). SBDD and SBDB phenotypes can be found almost exclusively on goat grass, which has enabled them to remain in the current population even though these phenotypes are avirulent to many wheat cultivars. Phenotypes FBMT, FMMG, PCRK, NBBJ, and NBGR occurred at low frequencies in areas 1 and 3 in 2002. These phenotypes are unique because they are avirulent to $L r 2 a$ and virulent to $L r 2 c$. These phenotypes also are avirulent to leaf rust-resistance genes in many common wheat cultivars, but have persisted in the $P$. triticina populations in the eastern United States. Phenotype BBBD is virulent only to $L r 14 a$ in the differential set used in the leaf rust nomenclature, yet six isolates of this phenotype were collected from wheat in Kansas and one isolate was collected from wheat in North Dakota. These phenotypes must survive on the small acreage of wheat cultivars that lack any leaf rust-resistance genes.

The two different applications of the Shannon index gave different rankings of phenotypic diversity for the $P$. triticina populations in areas 1 to 7 . The standard, uncorrected Shannon index is influenced by sample size (5), because area 2 with a sample size of 14 had the lowest measure of diversity. However, using the Shannon index corrected for sample size, the population in area 2 was tied with area 1 for the second most diverse population. The populations in areas 1 and 3 were ranked as either the most or second most diverse using both indices. The $P$. triticina population in area 1 is diverse due to the potential overwintering of leaf rust throughout this area, which can result in locally distinct populations of virulence phenotypes, and also due to the extensive use of cultivars with different combinations of resistance genes $\operatorname{Lr} 2 a, \operatorname{Lr} 9, \operatorname{Lr} 10$, $L r 11$, and $L r 18$ in this area (11). The Ohio Valley region of area 3 receives urediniospore inoculum from infected wheat fields in areas 1 and 4, which increases the diversity of phenotypes in this region. The $P$. triticina population in area 5 was the least diverse using both indices. This is due to the preponderance of Jagger wheat that is grown in Kansas and Nebraska, which has strongly selected phenotypes with virulence to $\mathrm{Lr} 17$ in this area.

In recent years, release of wheat cultivars with genes $\operatorname{Lr} 9, \operatorname{Lr} 16, \operatorname{Lr} 17, \operatorname{Lr} 24$, and Lr26 has caused rapid increases in virulent phenotypes of $P$. triticina. Recurrent mutation has resulted in a number of phenotypes with virulence to these genes. Virulence to $\operatorname{Lr} 9$ occurred in eight phenotypes in 2002, mostly TL-- or TN-- phenotypes that were found in areas 1, 2, 3, and 4. Virulence to Lr16 was in eight phenotypes, mostly TH-- or TG-- phenotypes in areas 4, 5, and 6. Virulence to $\operatorname{Lr} 17$ was found in 11 phenotypes. Phenotype TGDS found in area 6 has combined virulence to Lr16 and Lr17, and may increase if cultivars with both resistance genes are released. Phenotype TCDS, found in area 4 , is unique because it has virulence to $\operatorname{Lr} 2 a, \operatorname{Lr} 17$, and $L r 26$. Virulence to $L r 24$ was found in only seven phenotypes in 2002, having declined in frequency from the late 1980s and early 1990s $(16,17)$. Virulence to $L r 26$ was found in 17 phenotypes in 2002.

The high degree of virulence variation combined with the continuing use of $\mathrm{Lr}$ genes in the different wheat breeding programs has resulted in regional populations 
of $P$. triticina in the United States that differ for predominant virulence phenotypes which change very rapidly in response to effective leaf rust-resistance genes in wheat cultivars. The detection of phenotypes with different combinations of virulence to genes $\operatorname{Lr} 2 a, L r 9, L r 16, L r 17$, $L r 24, L r 26$, and $L r 41$ indicates that virulent phenotypes can increase rapidly in response to any new cultivars that have combinations of these resistance genes. Long-lasting or durable resistance to $P$. triticina in wheat will be achieved only by using genes such as Lr34 that have been shown to condition nonspecific resistance $(7,12)$. Wheat cultivars that have Lr34 combined with Lr46 (23) and other genes that condition partial resistance (22) have shown high levels of durable resistance in different wheat-growing regions of the world.

\section{LITERATURE CITED}

1. Chester, K. S. 1946. The Nature and Prevention of the Cereal Rusts as Exemplified in the Leaf Rust of Wheat. Chronica Botanica, Waltham, MA.

2. Dyck, P. L., and Samborski, D. J. 1974. Inheritance of virulence in Puccinia recondita on alleles at the Lr2 locus for resistance in wheat. Can. J. Genet. Cytol. 16:323-332.

3. Dyck, P. L., Samborski, D. J., and Anderson, R. G. 1966. Inheritance of adult-plant leaf rust resistance derived from the common wheat varieties Exchange and Frontana. Can. J. Genet. Cytol. 8:665-671.
4. Kolmer, J. A. 1989. Virulence and race dynamics of Puccinia recondita $\mathrm{f}$. sp. tritici in Canada during 1956-1987. Phytopathology 79:349-356.

5. Kolmer, J. A. 1991. Phenotypic diversity in two populations of Puccinia recondita $\mathrm{f}$. $\mathrm{sp}$. tritici in Canada during 1931-1987. Phytopathology 81:311-315.

6. Kolmer, J. A. 1991. Evolution of distinct populations of Puccinia recondita f. sp. tritici in Canada. Phytopathology 81:316-322.

7. Kolmer, J. A. 1997. Virulence in Puccinia recondita $\mathrm{f}$. sp. tritici isolates from Canada to genes for adult-plant resistance to wheat leaf rust. Plant Dis. 81:267-271.

8. Kolmer, J. A. 1999. Physiologic specialization of Puccinia triticina in Canada in 1997. Plant Dis. 83:194-197.

9. Kolmer, J. A. 1999. Virulence dynamics, phenotypic diversity, and virulence complexity in two populations of Puccinia triticina in Canada from 1987-1997. Can. J. Bot. 77:333-338.

10. Kolmer, J. A. 2002. Virulence phenotypes of Puccinia triticina in the South Atlantic States in 1999. Plant Dis. 86:288-291.

11. Kolmer, J. A. 2003. Postulation of leaf rust resistance genes in selected soft red winter wheats. Crop Sci. 43:1266-1274.

12. Kolmer, J. A., Long, D. L., Kosman, E., and Hughes, M. E. 2003. Physiologic specialization of Puccinia triticina on wheat in the United States in 2001. Plant Dis. 87:859-866.

13. Long, D. L., and Hughes, M. E 2003. Small Grain Losses to Rust. U. S. Dep. Agric. Res. Serv. Cereal Dis. Lab. On-line, publication CDL-EP\#007. Updated annually.

14. Long, D. L., and Kolmer, J. A. 1989. A North American system of nomenclature for $\mathrm{Puc}$ cinia recondita f. sp. tritici. Phytopathology 79:525-529.
15. Long, D. L., Leonard, K. J., and Hughes, M. E. 2000. Virulence of Puccinia triticina on wheat in the United States from 1996 to 1998. Plant Dis. 84:1334-1341.

16. Long, D. L., Leonard, K. J., and Roberts, J. J. 1998. Virulence and diversity of wheat leaf rust in the United States in 1993 to 1995. Plant Dis. 82:1391-1400.

17. Long, D. L., Roelfs, A. P., and Roberts, J. J. 1992. Virulence of Puccinia recondita f. sp. tritici in the United States during 1988-1990. Plant Dis. 76:495-499.

18. McIntosh, R. A., Wellings, C. R. and Park, R. F. 1995. Wheat Rusts: an Altas of Resistance Genes. CSIRO Australia, Kluwer Academic Publishers, Dordrecht, The Netherlands.

19. Samborski, D. J. 1985. Wheat leaf rust. Pages 39-59 in: The Cereal Rusts, Vol. 2. A. P. Roelfs and W. R. Bushnell, eds. Academic Press, Orlando, FL.

20. Samborski, D. J., and Dyck, P. L. 1968. Inheritance of virulence in wheat leaf rust on the standard differential wheat varieties. Can. J. Genet. Cytol. 10:24-32

21. Singh, R. P. 1991. Pathogenicity variations of Puccinia recondita f. sp. tritici and $P$. graminis f. sp. tritici in wheat-growing areas of Mexico during 1988 and 1989. Plant Dis. 75:790-794.

22. Singh, R. P., Huerta-Espino, J., and Rajaram, S. 2000. Achieving near-immunity to leaf rust and stripe rust in wheat by combining slow rusting resistance genes. Acta Phytopathol. Entomol. 35:133-139.

23. Singh, R. P., Mujeeb-Kazi, A., and HuertaEspino, J. 1998. Lr46: A gene conferring slowrusting resistance to leaf rust in wheat Phytopathology 88: 890-894.

24. Singh, R. P., and Rajaram, S. 1992. Genetics of adult-plant resistance in Frontana and three CIMMYT wheats. Genome 35:24-31. 